\title{
Multivariate Analysis of Variance of Effect of Extra Lesson on Secondary School Students' Academic Performance in English Language and Mathematics in Kwara State
}

\author{
Udokang, Anietie Edem, Odeyemi, Joseph Bamidele
}

\begin{abstract}
The study examined the Multivariate Analysis of duration and type of extra lessons undertaken by students and their effects on academic performance in secondary school using Multivariate Analysis of Variance (MANOVA). The study covers some selected schools in each of the three senatorial districts (zones) of Kwara State, Nigeria. The data collected was through the use of questionnaire and assessment test in English Language and Mathematics from 1191 randomly selected students. The outcome of MANOVA shown that type and duration of extra lessons contributed significantly to the performance of students in English Language and Mathematics combined together but their interaction was not significant. Further study using Analysis of Variance (ANOVA) revealed that type and duration of extra lessons have significant effect on students' academic performance in English Language as well as Mathematics. The pair of school and home extra lessons with school and holiday extra lessons were responsible for the significant effects. In the duration of extra lesson three pairs of combinations; an hour and more than 3 hours extra lessons, 2 hours and more than 3 hours extra lessons and 3 hours and more than 3 hours extra lessons contributed significantly to the students' academic performance in English Language as well as Mathematics. The holiday extra lesson and home extra lesson did better when compared to school extra lesson, hence the two are recommended for students with a duration that will not affects their extracurricular activities
\end{abstract}

Keywords: Type of extra lesson, Duration of extra lesson, Academic performance, Assessment, Multivariate analysis of variance

\section{INTRODUCTION}

Secondary school education in Nigeria has witnessed many policies implementations that led to the current three years in Junior Secondary School (JSS) and three years in Senior Secondary School when the 6-3-3-4 basic educational system was adopted in 1988. This system has been embraced by many for its ability to improve the standard of education which lead to good academic performance. The policy will be a success if is being funded by government with adequate provision of infrastructure and instructional facilities that would create the enabling environment for the policy to succeed [1].

The two subjects, English Language and Mathematics, considered in this paper are compulsory subjects for all the students in secondary schools in Nigeria no matter the

Udokang, Anietie Edem, Department of Statistics, The Federal Polytechnic, Offa, Kwara State, Nigeria, +2348052082590.

Odeyemi, Joseph Bamidele, Department of Statistics, The Federal Polytechnic, Offa, Kwara State, Nigeria, +2348066937363 category of subjects' combinations. The students are grouped/categorized into three made up science, arts and commercial at the Senior Secondary School (SSS) with different subjects' combinations while those in Junior Secondary School (JSS) offer all subjects which cut across science, arts and commercial.

Extra lesson has been mostly used for students by stakeholders as parents and teachers for English Language and Mathematics which led to the choice of these two subjects for this study. The issue now is do the extra lesson impart more knowledge on students to make a significant progress in their result? The parents, guardians and other stakeholders have spent so much resources (money and time) on extra lesson which the true worth of it must be investigated to know whether it should be encouraged. The report of the National Population Commission on Basic Education Profile for North East Nigeria revealed that 38 percent of parental contribution and involvement in money and time goes to extra lesson [2].

The extra lesson in the context of this paper is viewed in angle of types as school extra lesson and duration of extra lesson as factors that affects students' academic performance in two compulsory subjects (English Language and Mathematics). The type of extra lesson grouped into school extra lesson, center lesson, home lesson and holiday lesson. While that of duration of extra lesson is categorized into 1hour, 2hours, 3hours and more than 3hours.

This paper is to determine the effects of these two factors on students' academic performance while paying attention to their interactions, leading to determining if the effect of type of extra lesson on students' academic performances in English Language and Mathematics were influence by duration of extra lesson.

\section{LITERATURE REVIEW}

The use of Multivariate Analysis of Variance (MANOVA) is not new in educational research but applications and results makes the different. One of the applications of MANOVA was to compare the support services to the size of the school's support staff and enrollment [3]. The study reveals among other things that there was significant relationship between enrollment and the provision of academic athletic support services.

One way MANOVA was used in examining the difference between the performance of students classified into non-athletes and athletes on the five ACT Scores in English Language, Mathematics, Science, Reading and composite as dependent variables [4]. It was found that there were significant differences on the ACT Score between the two groups of students. Further investigation using analysis of 


\section{Multivariate Analysis of Variance of Effect of Extra Lesson on Secondary School Students' Academic Performance in English Language and Mathematics in Kwara State}

variance shows that athletes significantly performs better than non-athletes in Mathematics and Sciences while non-athletes performed significantly better in Reading than athletes.

MANOVA has also been used to find out if there was any significant different in students' academic performance between three Faculties of Agriculture and Life Sciences, Pure and Applied Sciences and Humanities, Management and Social Sciences of University of Federal University Wukari [5]. The result from the research showed that there exists no significant difference in the academic performance of the students in the three Faculties.

Some researchers also used the univariate aspect of analysis of variance known as NOVA to determine academic performance of students based on some factors. One of these works is the used ANOVA to analyse the data collected on family type and academic performance in which result from the analysis revealed that type of family significantly influenced students' academic performance [6].

The analysis of variance (ANOVA) was the statistical tool used in carrying out investigation on students' academic performance as a function of socio-economic status, parental education and occupation [7]. The study showed that students' academic achievement was only significantly influenced by socio-economic status and parents' education. In general family involvement students' academic performance is important to young children's literacy [8].

There are many other research articles on students' academic performance that uses other statistical tools apart from MANOVA to determine the effect of some factors on academic performance. Logistic regression was used in studying the effect of academic background, percentage of checkmarks in general knowledge, perceived efficiency, aptitude, interest in biological sciences and health, follow established regulations, drive and the pursue of social prestige on first year medical students' academic performance [9]. The research identified logistic regression as an efficient for valid conclusion. Also, Logistic regression as a statistical tool was used to study forty-one factors on academic performance of students of university of Maiduguri in MTH 101 [10].

The statistical tools used in various researches in studying academic performance are numerous but each author tries to use a set of independent variables (factors) that sometimes are different from each other [11], [12], [13], [14].

This paper focuses its attention to extra lesson which was also considered in another research [15] but for this paper extra lesson is considered in terms of type and duration. The extra lesson in this research article will uniquely be considered in two dimensions, which are the type of extra lesson and the duration of extra lesson.

\section{RESEARCH INSTRUMENTS}

This paper used questionnaire and assessment test as the major instruments of gathering information/data. There were two types of questionnaires which were constructed for JSS II students and another one for SSS II students. The questionnaires were validated by experts and reliability test using split-half reliability with coefficient of 0.86 JSS II questionnaire and 0.82 for SSS II questionnaire.

The assessment were set of questions which covers English Language and Mathematics for JSS II and SS II. The questions were set by professional teachers based on their core areas of interest in teaching.

\section{SAMPLING TECHNIQUES}

The secondary schools in Kwara were grouped into the five senatorial districts/zones and in each zone were schools were classified as urban area and rural area. The schools in these two area were subsequently grouped into private and public schools. A total of eight schools were randomly selected from each zone which made up of five public schools and three private schools.

Thereafter, twenty-five students were randomly selected each from JSS II and SS II classes except where the students were not up to twenty-five.

\section{DATA COLLECTION}

The data used in this study came from the use of questionnaire in which data was collected on the type of extra lesson and duration of extra lesson. The imputation of the data from the questionnaire was done through the use of SPSS. There were a total of 1191 students randomly selected from JSS II and SSS II of the selected schools. The data on academic performance was collected from two assessment test in English Language and two assessment test in Mathematics for JSS II and SS II. The first assessment was based on syllabus while the second one was on general intelligent questions in the two subjects.

It is pertinent to note that the scores obtained from the assessment test may not reflect the scores of these students in other examinations especially in public examinations, where dates of examinations are given for a long period of time for students to prepare, because it was impromptus. That notwithstanding the pattern of performance is believed to be the same based on the knowledge acquired through class lesson and extra lesson.

\section{TWO-WAY MULTIVARIATE ANALYSIS OF VARIANCE (MANOVA)}

The use of MANOVA is adopted for this study because of its advantages over univariate Analysis of Variance (ANOVA) with only one response variable. The analysis could as well use performance in English Language as a response variable and performance in Mathematics as a separate response variable as a separate analysis under ANOVA.

The calculations in MANOVA is based on matrix approach because there are more than one response variables which are students' academic performance in English Language and that of Mathematics. The independent variables are types of extra lesson (school extra lesson, center lesson, home lesson and holiday lesson) and duration of extra lesson (1hour, 2hours, 3 hours and more than 3 hours). The total sum of squares of and cross product matrix (SSCPT) is partitioned in terms of between sum-of-squares and cross-products matrix (SSCPB) and a within sum-of-squares and cross-products matrix (SSCPW) with the equation below

$$
S S C P_{\text {Total }}=S S C P_{\text {Between }}+S S C P_{\text {Within }} \text { [16]. }
$$

After using matrix approach in computations to get F-ratio and the $\mathrm{p}$ - value which in turn are used to decide on which of the following hypotheses to accept.

\section{Hypothesis 1}


$\mathrm{H}_{01}$ : Students' academic performance in English Language and Mathematics is not significantly influenced by type of extra lesson undertaken by the students

Vs

$\mathrm{H}_{11}$ : Students' academic in English Language and Mathematics is significantly influenced by type of extra lesson undertaken by the students

\section{Hypothesis 2}

$\mathrm{H}_{02}$ : Students' academic in English Language and Mathematics is not significantly influenced by duration of extra lesson undertaken by the students

Vs

$\mathrm{H}_{12}$ : Students' academic in English Language and Mathematics is significantly influenced by duration of extra lesson undertaken by the students

\section{Hypothesis 3}

$\mathrm{H}_{03}$ : There is no significant difference between interaction of type and duration of extra lesson on students' academic performance in English Language and Mathematics

Vs
$\mathrm{H}_{13}$ : There is no significant difference between interaction of type and duration of extra lesson on students' academic performance in English Language and Mathematics

\section{RESULT AND DISCUSSION}

Table 1: Box's Test for Homogeneity of Variance-Covariance

\begin{tabular}{|l|l|}
\hline Box's M & 287.812 \\
F & 6.295 \\
df1 & 45 \\
df2 & 330938.687 \\
Sig. & .000 \\
\hline
\end{tabular}

The Box's test of equality of variance in the table above is significant at with p-value $=0.05$ at $5 \%$ level of significance, meaning that there is unequal variance among groups. The Pillai's test is therefore recommended for the interpretation of MANOVA output.

Table 2: MANOVA

\begin{tabular}{|c|c|c|c|c|c|c|c|}
\hline Effect & & Value & $\mathrm{F}$ & $\begin{array}{l}\text { Hypoth-e } \\
\text { sis df }\end{array}$ & Error df & Sig. & $\begin{array}{l}\quad \text { Partial } \\
\text { Eta } \\
\text { Squared }\end{array}$ \\
\hline \multirow{5}{*}{ Intercept } & Pillai's Trace & .995 & $125087.018^{\mathrm{b}}$ & 2.000 & 1174.000 & .000 & .995 \\
\hline & Wilks' Lambda & .005 & $125087.018^{\mathrm{b}}$ & 2.000 & 1174.000 & .000 & .995 \\
\hline & Hotelling's Trace & 213.095 & $125087.018^{\mathrm{b}}$ & 2.000 & 1174.000 & .000 & .995 \\
\hline & Roy's Largest Root & 213.095 & $125087.018^{\mathrm{b}}$ & 2.000 & 1174.000 & .000 & .995 \\
\hline & Pillai's Trace & .011 & 2.247 & 6.000 & 2350.000 & .036 & .006 \\
\hline \multirow{3}{*}{$\begin{array}{l}\text { Type_of_Extra_ } \\
\text { lesson }\end{array}$} & Wilks' Lambda & .989 & $2.248^{\mathrm{b}}$ & 6.000 & 2348.000 & .036 & .006 \\
\hline & Hotelling's Trace & .011 & 2.248 & 6.000 & 2346.000 & .036 & .006 \\
\hline & Roy's Largest Root & .009 & $3.646^{\mathrm{c}}$ & 3.000 & 1175.000 & .012 & .009 \\
\hline \multirow{4}{*}{$\begin{array}{l}\text { Duration_of_ext } \\
\text { ra_lesson }\end{array}$} & Pillai's Trace & .019 & 3.769 & 6.000 & 2350.000 & .001 & .010 \\
\hline & Wilks' Lambda & .981 & $3.776^{\mathrm{b}}$ & 6.000 & 2348.000 & .001 & .010 \\
\hline & Hotelling's Trace & .019 & 3.783 & 6.000 & 2346.000 & .001 & .010 \\
\hline & Roy's Largest Root & .017 & $6.643^{c}$ & 3.000 & 1175.000 & .000 & .017 \\
\hline Type_of_Extra_ & Pillai's Trace & .023 & 1.552 & 18.000 & 2350.000 & .064 & .012 \\
\hline lesson $*$ & Wilks' Lambda & .977 & $1.553^{\mathrm{b}}$ & 18.000 & 2348.000 & .064 & .012 \\
\hline \multirow{2}{*}{$\begin{array}{l}\text { Duration_of_extra } \\
\text { lesson }\end{array}$} & Hotelling's Trace & .024 & 1.554 & 18.000 & 2346.000 & .064 & .012 \\
\hline & Roy's Largest Root & .018 & $2.363^{\mathrm{c}}$ & 9.000 & 1175.000 & .012 & .018 \\
\hline
\end{tabular}

The table above shows that type of extra lesson has significant influence or effects on a combination of students' academic performance in English Language and Mathematics $(p$-value $=0.036)$ at $5 \%$ level of significance. Using the same level of significance of $5 \%$, duration of extra lesson has significant effects on a combination of students' academic performance in English Language and Mathematics ( $p$-value $=0.001)$. Whereas, the interaction of extra lesson and duration of extra lesson do not have significant effect on a combination of students' academic performance in English Language and Mathematics ( $p$-value $=0.064$ ).

In order to determine the effects of these two factors (English Language and Mathematics) in students' academic performance in English Language separate from its effects in Mathematics, there is need for univariate analysis of variance (ANOVA) which is in the table below. 
Multivariate Analysis of Variance of Effect of Extra Lesson on Secondary School Students' Academic Performance in English Language and Mathematics in Kwara State

Table 3: ANOVA

\begin{tabular}{|c|c|c|c|c|c|c|c|}
\hline Source & Dependent Variable & $\begin{array}{l}\text { Type I Sum of } \\
\text { Squares }\end{array}$ & $\mathrm{df}$ & Mean Square & $\mathrm{F}$ & Sig. & \begin{tabular}{|c|} 
Partial \\
Eta Squared
\end{tabular} \\
\hline \multirow{2}{*}{ Corrected Model } & English_Score & $11476.335^{\mathrm{a}}$ & 15 & 765.089 & 2.668 & .001 & .033 \\
\hline & Mathematics_Score & $16980.227^{\mathrm{D}}$ & 15 & 1132.015 & 2.675 & .001 & .033 \\
\hline \multirow{2}{*}{ Intercept } & English_Score & 4588501.784 & 1 & 4588501.784 & 16001.008 & .000 & .932 \\
\hline & Mathematics_Score & 4103147.637 & 1 & 4103147.637 & 9696.345 & .000 & .892 \\
\hline \multirow{2}{*}{ Type_of_Extra_lesson } & English_Score & 2950.282 & 3 & 983.427 & 3.429 & .017 & .009 \\
\hline & Mathematics Score & 4235.109 & 3 & 1411.703 & 3.336 & .019 & .008 \\
\hline \multirow{2}{*}{ Duration_of_extra_lesson } & English_Score & 5602.280 & 3 & 1867.427 & 6.512 & .000 & .016 \\
\hline & Mathematics_Score & 8119.990 & 3 & 2706.663 & 6.396 & .000 & 016 \\
\hline \multirow{4}{*}{$\begin{array}{l}\text { Type_of_Extra_lesson } \\
\text { Duration_of_extra_lesson } \\
\text { Error }\end{array}$} & English_Score & 2923.773 & 9 & 324.864 & 1.133 & .336 & .009 \\
\hline & Mathematics_Score & 4625.127 & 9 & 513.903 & 1.214 & .282 & .009 \\
\hline & English_Score & 336946.881 & 1175 & 286.763 & & & \\
\hline & Mathematics_Score & 497218.136 & 1175 & 423.164 & & & \\
\hline \multirow{2}{*}{ Total } & English_Score & 4936925.000 & 1191 & & & & \\
\hline & Mathematics_Score & 4617346.000 & 1191 & & & & \\
\hline \multirow{2}{*}{ Corrected Total } & English_Score & 348423.216 & 1190 & & & & \\
\hline & Mathematics_Score & 514198.363 & 1190 & & & & \\
\hline
\end{tabular}

The result from analysis of variance as exhibited in table 3 shows that there is significant influence of type of extra lesson on students' academic performance in English Language as well Mathematics at $5 \%$ level of significance with p-values of 0.017 for English language and 0.019 for Mathematics. The work of [15] also supported that extra lesson has effect on

There is also a significant influence of duration of extra lesson on students' academic performance in English Language as well Mathematics but at any level of significance with p-values of 0.000 for English language and 0.000 for Mathematics. students' academic performance.

Table 4: Post Hoc (Type of extra lesson)

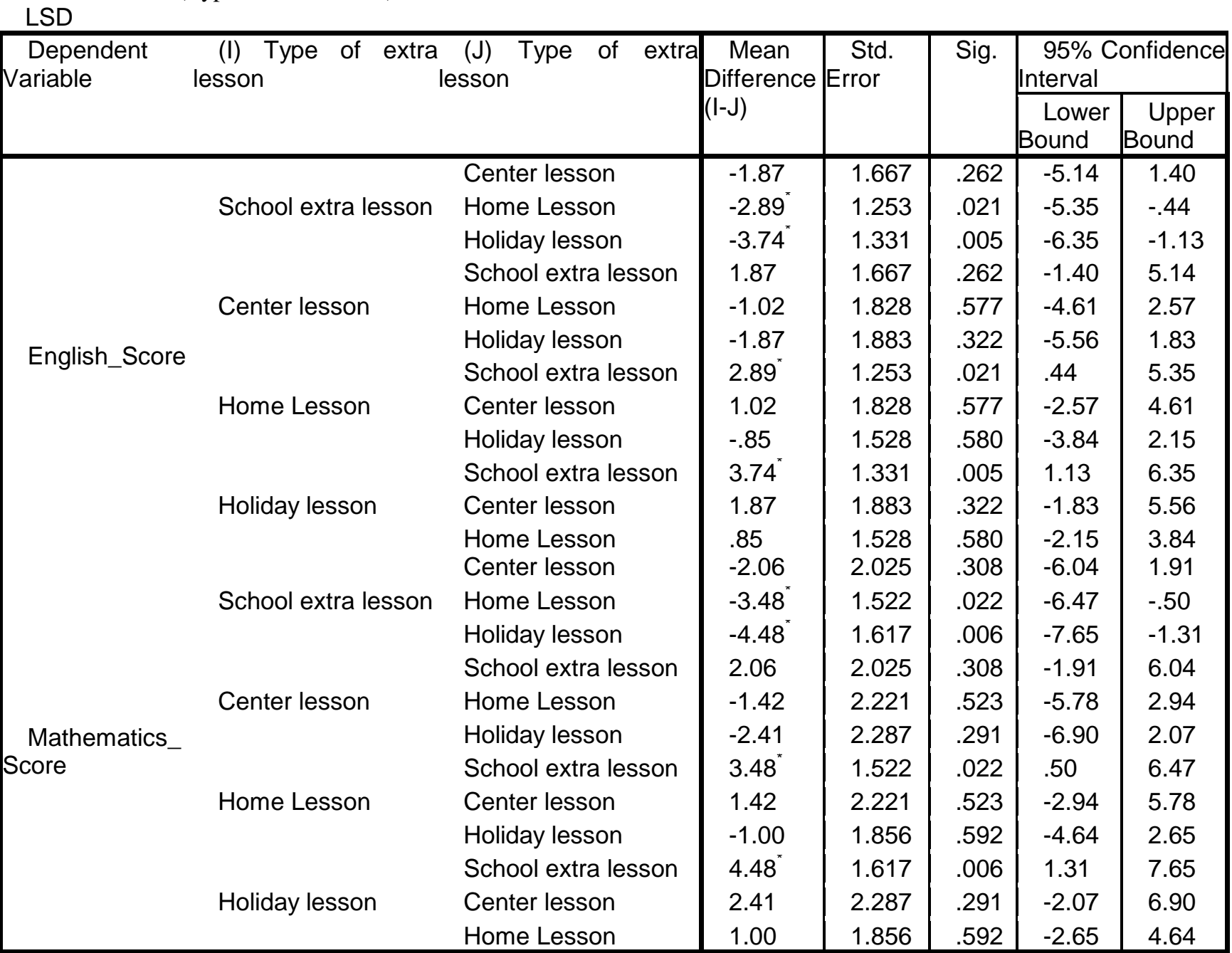

Looking for the pair of type of extra lesson that bring about the significant effects on students' academic performance in English Language as well as Mathematics at 5\% level of significant. Table 7 shows that two pairs of combinations, school extra lesson and home extra lesson $(p$-value $=0.021)$ and school extra lesson and holiday extra lesson ( $\mathrm{p}$-value = 0.005 ) contributed significantly to the students' academic performance in English Language. The same two pairs of combinations, school extra lesson and home extra lesson $(\mathrm{p}$-value $=0.022)$ and school extra lesson and holiday extra 
lesson ( $\mathrm{p}$-value $=0.006$ ) contributed significantly to the students' academic performance in Mathematics.

A closer look at difference in mean of the combinations indicates that both home and holiday extra lessons contributes more to the performance of students in both English Language and Mathematics.

Table 5: Post Hoc (Duration of extra lesson) LSD

\begin{tabular}{|c|c|c|c|c|c|c|c|}
\hline \multirow[t]{2}{*}{$\begin{array}{l}\text { Dependent } \\
\text { Variable }\end{array}$} & \multirow{2}{*}{\multicolumn{2}{|c|}{$\begin{array}{l}\text { (I) Duration of extra }(\mathrm{J}) \text { Duration of extra } \\
\text { lesson }\end{array}$}} & \multirow{2}{*}{\begin{tabular}{l}
\multicolumn{1}{c}{ Mean } \\
Difference \\
$(\mathrm{I}-\mathrm{J})$
\end{tabular}} & \multirow[t]{2}{*}{$\begin{array}{l}\text { Std. } \\
\text { Error }\end{array}$} & \multirow[t]{2}{*}{ Sig. } & \multicolumn{2}{|c|}{$\begin{array}{cc}95 \% & \text { Confidence } \\
\text { Interval } & \end{array}$} \\
\hline & & & & & & $\begin{array}{l}\text { Lower } \\
\text { Bound }\end{array}$ & $\begin{array}{l}\text { Upper } \\
\text { Bound }\end{array}$ \\
\hline \multirow{16}{*}{ English_Score } & \multirow{4}{*}{ An Hour } & 2Hours & -.46 & 1.294 & .724 & -2.99 & 2.08 \\
\hline & & 3 Hours & .27 & 1.375 & .842 & -2.42 & 2.97 \\
\hline & & More than 3 Hours & $-6.43^{x}$ & 1.609 & .000 & -9.58 & -3.27 \\
\hline & & An Hour & .46 & 1.294 & .724 & -2.08 & 2.99 \\
\hline & \multirow[t]{2}{*}{ 2Hours } & 3 Hours & .73 & 1.275 & .567 & -1.77 & 3.23 \\
\hline & & More than 3 Hours & $-5.97^{x}$ & 1.525 & .000 & -8.96 & -2.98 \\
\hline & \multirow{3}{*}{3 Hours } & An Hour & -.27 & 1.375 & .842 & -2.97 & 2.42 \\
\hline & & 2Hours & -.73 & 1.275 & .567 & -3.23 & 1.77 \\
\hline & & More than 3 Hours & $-6.70^{\pi}$ & 1.594 & .000 & -9.83 & -3.57 \\
\hline & \multirow{3}{*}{ More than 3 Hours } & An Hour & $6.43^{\pi}$ & 1.609 & .000 & 3.27 & 9.58 \\
\hline & & 2Hours & $5.97^{*}$ & 1.525 & .000 & 2.98 & 8.96 \\
\hline & & $\begin{array}{l}3 \text { Hours } \\
2 \text { Hours }\end{array}$ & $\begin{array}{l}6.70^{*} \\
-.70\end{array}$ & $\begin{array}{l}1.594 \\
1.571\end{array}$ & $\begin{array}{l}.000 \\
.655\end{array}$ & $\begin{array}{l}3.57 \\
-3.79\end{array}$ & $\begin{array}{l}9.83 \\
2.38\end{array}$ \\
\hline & \multirow[t]{2}{*}{ An Hour } & 3 Hours & .25 & 1.670 & .883 & -3.03 & 3.52 \\
\hline & & More than 3 Hours & $-7.79^{*}$ & 1.955 & .000 & -11.63 & -3.96 \\
\hline & & An Hour & .70 & 1.571 & .655 & -2.38 & 3.79 \\
\hline & 2Hours & 3 Hours & .95 & 1.549 & .541 & -2.09 & 3.99 \\
\hline \multirow{7}{*}{$\begin{array}{l}\text { Mathematics_S } \\
\text { core }\end{array}$} & & More than 3 Hours & $-7.09^{\star}$ & 1.852 & .000 & -10.72 & -3.45 \\
\hline & \multirow{3}{*}{3 Hours } & An Hour & -.25 & 1.670 & .883 & -3.52 & 3.03 \\
\hline & & 2Hours & -.95 & 1.549 & .541 & -3.99 & 2.09 \\
\hline & & More than 3 Hours & $-8.04^{\pi}$ & 1.937 & .000 & -11.84 & -4.24 \\
\hline & \multirow{3}{*}{ More than 3 Hours } & An Hour & $7.79^{*}$ & 1.955 & .000 & 3.96 & 11.63 \\
\hline & & 2Hours & $7.09^{\pi}$ & 1.852 & .000 & 3.45 & 10.72 \\
\hline & & 3 Hours & $8.04^{*}$ & 1.937 & .000 & 4.24 & 11.84 \\
\hline
\end{tabular}

Considering the Post Hoc test for the pair of durations of extra lesson that contributed significantly to the students' academic performance in English Language separate from Mathematics at 5\% level of significant. Table 5 shows that three pairs of combinations, an hour extra lesson and more than 3 hours extra lesson ( $p$-value $=0.000$ ), 2 hours extra lesson and more than 3 hours extra lesson ( $p$-value $=0.000)$ and 3 hours and more than 3 hours extra lesson ( $\mathrm{p}$-value = 0.000 ) contributed significantly to the students' academic performance in English Language. The same three pairs of combinations; an hour extra lesson and more than 3 hours extra lesson ( $\mathrm{p}$-value $=0.000), 2$ hours extra lesson and more than 3 hours extra lesson $(p$-value $=0.000)$ and 3 hours and more than 3 hours extra lesson ( $\mathrm{p}$-value $=0.000$ ), also contributed significantly to the students' academic performance in Mathematics.

A closer look at difference in mean of the combinations indicates that more than 3 hours extra lessons contributes more to the performance of students in both English Language and Mathematics than an hour, one hour and three hours of extra lesson.

\section{CONCLUSION}

The introduction of extra lesson has brought improvement on students' academic performance in English Language and Mathematics. The type of extra lesson that can be encouraged in order of their important are holiday extra lesson, home extra lesson and school extra lesson. Considering the duration of extra lesson, the result shows that the longer period of lesson (more than three hours) are of advantage of a better result.

\section{RECOMMENDATIONS}

The participation of students in extra lesson is very important to improve their performance in the core subjects of English Language and Mathematics.

Therefore, holiday extra lesson and home lesson is recommended for students with a duration that will not affects their extracurricular activities, even though the longer the duration the better. Further researches is encouraged in this area, especially on duration to really determine a duration based on other factors to bring about equilibrium on the negative effect of being too longer. 


\section{Multivariate Analysis of Variance of Effect of Extra Lesson on Secondary School Students' Academic Performance in English Language and Mathematics in Kwara State}

\section{ACKNOWLEDGEMENTS}

I wish to appreciate the Tertiary Education Trust Fund (TETFUND), Nigeria for making this research a reality by its sponsorship under the Institution Based Research Grant. My sincere gratitude also goes to Federal Polytechnic, Offa for the opportunity to participate in the TETFUND grant.

\section{REFERENCES}

[1] O. Edeku (2020). Evaluating The 6-3-3-4 System of Education in Nigeria. Saturday, July 25,2020. http://thepointernewsonline.com/?p=54376

[2] National Population Commission (2004). Basic Education Profile for North East Nigeria. Section 4.

[3] J. Butterworth and J. Rich (2003). Examining Academic-Athletic Support and Academic Success of Student Athletes. Honors Theses and Capstones. 98.

[4] A. Lumpkin and J. Favor (2012). Comparing the academic performance of high school athletes and non-athletes in Kansas in 2008-2009. Journal of Sport Administration \& Supervision 4(1), 41-62.

[5] E. N. Okeke, J. U. Okeke and D. Adashu (2018). Multivariate Analysis of Variance of University Students' Academic Performance. International Journal of Applied Mathematics \& Statistical Sciences (IJAMSS), Vol. 7, Issue 1, $13-20$.

[6] R. E. Ella, A. O. Odok and G. E. Ella (2015). Influence of Family Size and Family Type on Academic Performance of Students in Government in Calabar Municipality, Cross River State, Nigeria. International Journal of Humanities Social Sciences and Education (IJHSSE), Volume 2, Issue 11, PP 108-114

[7] M. S. Farooq, A.H. Chaudhry, M. Shafiq and G. Berhanu (2011) Factors Affecting Students' Quality of Academic Performance: A Case of Secondary School Level. Journal of Quality and Technology Management, Volume VII, Issue II, PP 01 - 14.

[8] L. V. Frances, F. M. Michelle, M. L. Chrishana and L. Therese (2013). The Impact of Family Involvement on the Education of Children Ages 3 to 8: A Focus on Literacy and Math Achievement Outcomes and Social-Emotional Skills. MDRC.

https://www.mdrc.org/publication/impact-family-involvement-educat ion-children-ages-3-8

[9] E. U. María, F. Ruth, D. M. M. Vargas, B. Edward, O. L. Silvia and G. Rosalinda (2016). Logistic Regression Model for the Academic Performance of First-Year Medical Students in the Biomedical Area. Creative Education, 7, 2202-2211.

[10] B. O. Sule and F.W.O. Saporu (2015). A Logistic Regression Model of Students' Academic Performance in University of Maiduguri, Maiduguri, Nigeria. Mathematical Theory and Modeling, Vol. 5, No 10, 2225-0522 (Online).

[11] G. Kiger \& D. Lorentzen (1987) Gender, academic performance and university athletes. Sociological Spectrum, 7:3, 209-222.

[12] M. Paulo, M. Fátima, C. Diana and A. I. Richard (2020). The Academic Performance Stages of Change Inventory (APSCI): An application of the Transtheoretical Model to academic performance. International Journal of School \& Educational Psychology, 8:3, $199-212$

[13] V. Carlos, V. Isabel and R. Luis (2018). Distance and academic performance in higher education. Spatial Economic Analysis, 13:1, 60-79.

[14] B. S. Christine (1996). Correlates of Engineering Freshman Academic Performance. European Journal of Engineering Education, 21:3, $317-326$

[15] S. Lochan and D. Barrow (2008). Extra -Lessons: A Comparison Between "Different Sides of the Track" in Trinidad and Tobago. Caribbean Curriculum, Vol. 15, 2008, PP 45-69

[16] C. A. Mertler and R. V. Reinhart (2017). Advanced and Multivariate Statistical Methods Practical Application and Interpretation Routledge, Taylor \& Francis Group. Sixth Edition. New York.

\section{First Author's Profile}

ANIETIE EDEM UDOKANG is a lecturer in Statistics Department, Federal Polytechnic, Offa, Kwara State, Nigeria with 23 years of lecturing experience. He has M.Sc. in Statistics (Time Series) from University of Nigeria, Nsukka. He is an author and co-author of many articles in international journals. He is a member of many professional bodies such as Nigerian Statistical Association (NSA), Association of Economist and Statisticians (Fellow) and Strategic Institute for Natural Resources and Human Development Nigeria (Fellow). He is the ogarniser of Offa R Users
Group formerly known as Fedpoffa $\mathrm{R}$ Users Group. He is married and blessed with children.

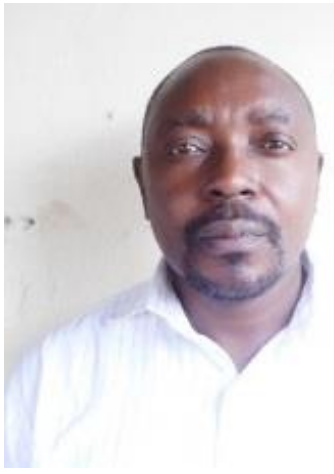

Second Author's Profile

ODEYEMI JOSEPH is a Principal Lecturer in the Department of Statistics at Federal Polytechnic, Offa, Kwara State, Nigeria. He is a Statistician and Archivist. He obtained B.Sc. in Statistics from Kwara State University, Molete and M.Sc. Statistics from University of Ilorin, Nigeria. Also, he is a holder of Masters of Archive and Records Management from the University of Ibadan, Nigeria. He has contributed as author and co-author to many articles in international journals. He is married and blessed with children.

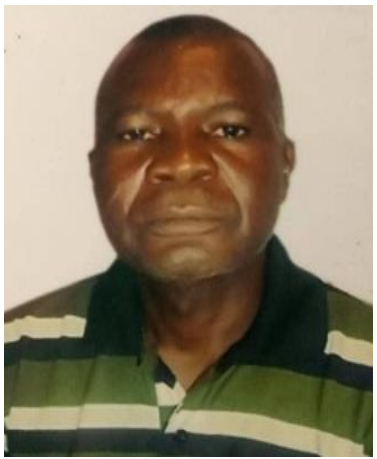

